\title{
EVALUATION OF CRUISER TRAFFIC VARIABLES IN SEAPORTS OF THE REPUBLIC OF CROATIA
}

\author{
Maja Račić, Katarina Balić, Mira Pavlinović, Antonija Mišura \\ University of Split (Croatia)
}

\begin{abstract}
The paper analyses the data on ship and passenger availability in the busiest ports in the Republic of Croatia. In order to evaluate the variables related to cruiser traffic in seaports in the period from 2015 to 2023 in the Republic of Croatia, it was first necessary to determine the following most important variables of the proposed model: the port of Dubrovnik, the port of Split, the port of Zadar, the port of Rijeka and the port of Šibenik.

The trends in passenger traffic from 2015 to 2023 for the five most important cruise ports in the Republic of Croatia were investigated. The values of the selected model variables were quantified on an index scale from zero to 100 .

This form of tourism is becoming more and more present on the international tourist market, offering numerous favourable opportunities, especially in the Mediterranean area. Due to its geo-traffic position, mild climate and rugged coastline, the Republic of Croatia is one of the most desirable cruising destinations in the world. The aim of this paper is to investigate and evaluate the cruise traffic variables of the busiest ports in the Republic of Croatia and to compare the observed ports with the port of Barcelona, as one of the most important ports for cruise ships in the Mediterranean. The conducted research indicates the constant growth of this form of tourism in the Republic of Croatia with the obligation to implement well-thought-out policies and strategies in order to achieve long-term sustainability. trips

Keywords: cruisers; quantification of variables; cruising; seaports for cruise
\end{abstract}

\section{Introduction}

Cruising involves transport of people by boat according to a predetermined timetable and program with various sporting, entertainment, health and other activities and services provided to passengers on a tourist travel for the purpose of rest, entertainment, and recreation. (Šamanović 2002) This form of tourism is becoming more prevalent in the international tourism market, offering a number of favourable opportunities, particularly in the Mediterranean area. The Mediterranean 
is the most important receptive cruise area in Europe, as $20 \%$ of the entire world fleet is operating in this area.

Due to its geo-traffic position, mild climate and indented coastline, the Republic of Croatia is one of the most desirable cruising destinations in the world. Domestic cruising in Croatia is one of the most desirable tourist products in Europe, and during the last ten years the number of mega cruiser arrivals has been constantly growing, indicating the possibility of its development and longterm survival. The constantly growing business results in cruising tourism must be accompanied by an appropriate strategy and policy, and above all by raising the quality of products.

Nautical tourism, i.e. yachting and cruising, in accordance with global market trends, are a particularly important group of products for the development of Croatian tourism.

Based on the analysis of the existing literature and statistical data, the aim of this paper is to investigate the overall movement of the number of passengers in the leading Croatian cruise ports. This paper gives a detailed statistical analysis of cruise tourism for the period from 2015 to 2019, the total number of passengers travelling to the largest Mediterranean cruise port Barcelona, as well as the most important cruise ports in the Republic of Croatia. Based on the above, the variables for 2023 were evaluated.

The following scientific methods were used: method of analysis and synthesis, inductive and deductive methods, methods of abstraction and concretization, methods of generalization and specialization, comparative method and method of evidence and objection.

In this scientific paper, the selected variables of Croatian cruise ports were quantified with an index scale from 0 to 100, for 2015, 2019 and 2023. The most important variables of this model are: the port of Dubrovnik, the port of Split, the port of Zadar, the port of Rijeka and the port of Šibenik.

\section{The port of Barcelona as the leading port of the Mediterranean}

The leading European cruise port, Barcelona, is also the city, the seaport, and the capital of the province of Catalonia. It is located in north-eastern Spain, 90 miles $(150 \mathrm{~km})$ south of the French border. It is a major Mediterranean port and trading centre and is known for its individuality, culture, and beauty.

The port of Barcelona has seven international passenger terminals and a wide range of specialized companies in the sector. It is a leader in security and specific logistics for cruise ships. The consolidation between the port and the city is extremely pronounced. The Port of Barcelona is also a Member of MedCruise, the Association of Mediterranean Cruise Ports (Peručić 2013). Carnival Corporation and the Carnival Group have invested $€ 100$ million in building terminals and upgrading facilities in recent years ${ }^{1)}$. 
Table 1. The total number of passenger movements and cruise ship in Barcelona in the period from 2015 to 2019

\begin{tabular}{|l|c|c|c|c|}
\hline Year & $\begin{array}{c}\text { Number of } \\
\text { passengers } \\
\text { (embarked/ } \\
\text { disembarked) }\end{array}$ & $\begin{array}{c}\text { Number of } \\
\text { passengers in transit }\end{array}$ & $\begin{array}{c}\text { Total number of } \\
\text { passengers (boarded } \\
\text { / disembarked + } \\
\text { transit) }\end{array}$ & Arrivals \\
\hline $\mathbf{2 0 1 5}$ & 1.363 .754 & 1.176 .548 & 2.540 .302 & 749 \\
\hline $\mathbf{2 0 1 6}$ & 1.555 .819 & 1.127 .775 & 2.683 .594 & 758 \\
\hline $\mathbf{2 0 1 7}$ & 1.440 .383 & 1.271 .864 & 2.712 .247 & 778 \\
\hline $\mathbf{2 0 1 8}$ & 1.666 .767 & 1.375 .196 & 3.041 .963 & 830 \\
\hline $\mathbf{2 0 1 9}$ & 1.753 .222 & 1.384 .696 & 3.137 .918 & 800 \\
\hline
\end{tabular}

In 2019, the port of Barcelona reached a record of more than 3 million passengers ${ }^{2}$. Barcelona recorded growth in 2018 and 2019 (Table 1). In the observed period, the lowest number of passengers was recorded in 2015, while in 2019 the number of passengers compared to 2015 increased by $22 \%$. Compared to 2018, an increase of $5 \%$ was recorded. The number of arrivals decreased by $3.6 \%$ compared to 2019 .

Barcelona, as the most popular cruise port in the Mediterranean, had more than 80,000 passengers in arrival/departure compared to 2018.

It can be concluded that the port of Barcelona has a tendency to continuously grow and to achieve long-term sustainability of this form of tourism as a leading cruise port in the Mediterranean.

\section{Cruise ports in the republic of Croatia}

According to the Croatian Bureau of Statistics, 75 foreign cruise ships entered Croatian seaports, with 710 cruises in the period from January to November 2019. There were 1.1 million passengers on these ships, who stayed in Croatia for 1,413 days. The largest number of voyages were made by ships flying the flag of Malta (199 voyages) and the Bahamas (127 voyages), while the largest number of passengers arrived by ships flying the flags of Panama (287 thousand passengers) and Malta (258 thousand passengers). Out of a total of 710 cruises, most trips were in the Dubrovnik-Neretva County (59.4\%) and the Split-Dalmatia County $(25.6 \%)$, which is a total of $85.0 \%$. The remaining $15.0 \%$ of trips were made in the following counties: Zadar County (6.5\%), Istria County (3.8\%), Primorje-Gorski Kotar County (3.1\%) and Šibenik-Knin County (1.6\%). The most visited seaports were Dubrovnik, Split and Zadar. The port of Dubrovnik had the most visits by foreign cruise ships (518 visits), followed by the ports of Split (267 visits) and the port of Zadar (117 visits $)^{3)}$.

Furthermore, due to the COVID-19 pandemic, measures were introduced to ban the entry of ships on international cruises, which directly affected the reduction of the number of foreign cruise ships in Croatian seaports in March 2020 and their 
absence in April, May, and June 2020. In the period from January to June 2020, the number of foreign cruise ships in Croatian seaports decreased by $88.9 \%$ compared to the same period in 2019.

\section{The port of Zadar}

The passenger-ferry port of Zadar, is located in the heart of the city, about 900 $\mathrm{m}$ from the coastline. It is connected by a modern highway to all neighbouring European countries ${ }^{4}$. In the last few years, the Port of Zadar has been recording more and more cruise ship arrivals with intensive local, coastal, and international traffic. Especially significant is the opening of the port of Zadar into a possible home port, the home port of large cruisers. The proximity of the airport $(10 \mathrm{~km})$ and the link between quality roads and a highway, are significant advantages of the ferry terminal.

A new passenger-ferry terminal in Zadar (Gaženica), was declared the best cruise port in the world in 2019, at the most prestigious fair of cruise industry in Hamburg. The Seatrade Cruise Awards are given to the best cruise port in competition with several hundred ports. The port of Zadar entered the finals together with the Norwegian port of Olden Leon and the Japanese port of Yokohama, and won as the port that has made the greatest progress in port management in the last year. The construction of the new terminal introduced the highest standards of port management and the best world practices (https://www.luka-zadar.hr/). The new passenger terminal in Gaženica is one of the most modern passenger terminals in the Mediterranean. It is a two-storey building that covers more than 18,000 square meters and is one of the largest buildings in the city of Zadar. At this terminal, not only cruise ships dock, but also all domestic and international traffic takes place.

Table 2. The total number of passenger and cruise ship movement in the port of Zadar in the period from 2015 to 2019

\begin{tabular}{|c|c|c|c|c|}
\hline Year & $\begin{array}{c}\text { Number of passengers } \\
\text { (embarked/ } \\
\text { disembarked) }\end{array}$ & $\begin{array}{c}\text { Number of } \\
\text { passengers } \\
\text { in transit }\end{array}$ & $\begin{array}{c}\text { Total number of } \\
\text { passengers (boarded / } \\
\text { disembarked+ transit) }\end{array}$ & Arrivals \\
\hline $\mathbf{2 0 1 5}$ & 1.064 & 73.596 & 74.660 & 96 \\
\hline $\mathbf{2 0 1 6}$ & 877 & 135.584 & 136.462 & 114 \\
\hline $\mathbf{2 0 1 7}$ & 736 & 136.931 & 137.667 & 104 \\
\hline $\mathbf{2 0 1 8}$ & 1051 & 165.477 & 166.528 & 133 \\
\hline $\mathbf{2 0 1 9}$ & 1369 & 181.665 & 183.034 & 131 \\
\hline
\end{tabular}

The Port of Zadar has only recently entered the global network of ports for cruises, and every year it records an increase in the number of passengers on cruises. Over a four-year period, the lowest number of passengers was recorded in 2015, 
while in 2019 the number of passengers compared to 2015 increased by $145 \%$. Comparing 2018 and 2019 (Table 2), an increase of 10\% was recorded. Taking into account the number of arrivals, there is an increase of $26 \%$ in 2019 compared to 2017 , and an increase a substantial $35 \%$ compared to 2015 . It can be concluded from Table 2 that the port of Zadar has a tendency to grow as a cruise port.

\section{The port of Rijeka}

The Port of Rijeka is the largest port in Croatia. The inner part of the port is for passenger traffic. The Port of Rijeka has an exceptional geo-traffic position. The draught with a depth of 16-metres allows the reception of the largest ships, and with some additional work the draught will be increased to 20 meters. The railway and bus stations are in the immediate vicinity of the port, which gives the port an additional advantage. The city centre is 50 to 300 meters away from the port.

The forecasts of the Port of Rijeka Authority for the coming years are high, and considering the reservations that have already been confirmed, 70,000 passengers are expected. It was not until 2014 that the Port of Rijeka Authority began concrete activities which aimed at defining the area for the reception of cruisers.

Table 3. The total number of passenger and cruise ship movement in the port of Rijeka in the period from 2015 to 2019

\begin{tabular}{|c|c|c|c|c|}
\hline Year & $\begin{array}{c}\text { Number of } \\
\text { passengers } \\
\text { (embarked/ } \\
\text { disembarked) }\end{array}$ & $\begin{array}{c}\text { Number of } \\
\text { passengers } \\
\text { in transit }\end{array}$ & $\begin{array}{c}\text { Total number of } \\
\text { passengers (boarded / } \\
\text { disembarked+ transit) }\end{array}$ & Arrivals \\
\hline $\mathbf{2 0 1 5}$ & 0 & 9.082 & 9.082 & 7 \\
\hline $\mathbf{2 0 1 6}$ & 0 & 13.874 & 13.874 & 15 \\
\hline $\mathbf{2 0 1 7}$ & 0 & 12.656 & 12.656 & 15 \\
\hline $\mathbf{2 0 1 8}$ & 0 & 10.913 & 10.913 & 11 \\
\hline $\mathbf{2 0 1 9}$ & 0 & 41.137 & 41.137 & 24 \\
\hline
\end{tabular}

In the Port of Rijeka, comparing 2017 and 2013, the number of passengers in transit increased by $1747.59 \%$. According to Table 3, in 2018 there was a decrease in passengers in transit by 1743 compared to 2017 , i.e. by $13.77 \%$. Compared to 2017 , there is also a decline in the number of cruise ships - the number of arrivals fell by $26.67 \%$ in 2018. A significant decline in the number of passengers began in 2017, where the total number of passengers decreased by $8.78 \%$, compared to 2016 . In 2019, there was an increase in passengers in transit by 286\% compared to 2018.

\section{The port of Split}

The port of Split is located in the central Adriatic and is an unavoidable destination for cruise ships. Since 2012, cruise ships have been arriving in the port 
of Split. In 2012, 82 ships with 20,616 passengers visited Split. The Port of Split has been visited by almost all world-famous shipping companies since 2002; Carnival Cruises, Royal Caribbean Cruises, MSC Cruises, Costa Crociere, Cunard Line, Radisson Cruises, Celebrity Cruise, Fred Olsen Cruise Line, Club Med Cruises, Thomson Cruises, P \& O Cruises, Norwegian Cruises Line, Viking Ocean Cruises, Princess Cruises, and many others. There is almost no shipowner who has not sent at least one ship from his fleet to the port of Split. Thanks to its strategic position in the Mediterranean (between Venice and the Aegean Sea), the port of Split is one of the most important ports of call for cruises in the Adriatic, and its long history and numerous sights attract thousands of tourists ${ }^{5)}$. The expansion and renewal of passenger berths on the outer side of the breakwater of the port of Split directly resulted in an increase in traffic capacity, both for land and sea transport.

Table 4. Total number of passenger and cruise ship movement in the port of Split in the period from 2015 to 2019

\begin{tabular}{|c|c|c|c|c|}
\hline Year & $\begin{array}{c}\text { Number of } \\
\text { passengers } \\
\text { (embarked/ } \\
\text { disembarked) }\end{array}$ & $\begin{array}{c}\text { Number of } \\
\text { passengers in } \\
\text { transit }\end{array}$ & $\begin{array}{c}\text { Total number of } \\
\text { passengers (boarded / } \\
\text { disembarked+ transit) }\end{array}$ & Arrivals \\
\hline $\mathbf{2 0 1 5}$ & 0 & 271.445 & 271.445 & 261 \\
\hline $\mathbf{2 0 1 6}$ & 879 & 274.772 & 275.651 & 286 \\
\hline $\mathbf{2 0 1 7}$ & 0 & 232.244 & 232.244 & 234 \\
\hline $\mathbf{2 0 1 8}$ & 0 & 307.139 & 307.139 & 260 \\
\hline $\mathbf{2 0 1 9}$ & 0 & 359.955 & 359.955 & 282 \\
\hline
\end{tabular}

In 2019, cruise ships visited the port of Split 282 times and achieved a record turnover of 359,955 passengers, which is an increase in the number of cruise passengers by $17 \%$ compared to 2018 , while arrivals recorded an increase of $8.4 \%$. Comparing the total number of passengers (embarked/disembarked and passengers in transit), there was an increase by $66.87 \%$ in 2018 in comparison with 2014 . Analysing the data from Table 4, it can be concluded that there was a decrease in the number of arrivals compared to 2016.

\section{The port of Dubrovnik}

Dubrovnik was one of the first ports that started with cruise ship tourism; and has been doing so for 165 years. After 1995, the port of Dubrovnik exclusively directed its development in the direction of the passenger port. The distance between the passenger port Gruž in Dubrovnik and the historic centre is 2 kilometres. Through the realization of some infrastructure projects, one area of the port is planned to be used exclusively for international and domestic passenger traffic, i.e. for cruise ships and luxury yachts. More than $€ 34$ million have so far been invested in the port ${ }^{6}$. 
Table 5. Total number of passenger and cruise ship movement in the port of Dubrovnik in the period from 2015 to 2019

\begin{tabular}{|c|c|c|c|c|}
\hline Year & $\begin{array}{c}\text { Number of passengers } \\
\text { (embarked/ } \\
\text { disembarked) }\end{array}$ & $\begin{array}{c}\text { Number of } \\
\text { passengers } \\
\text { in transit }\end{array}$ & $\begin{array}{c}\text { Total number of } \\
\text { passengers (boarded / } \\
\text { disembarked+ transit) }\end{array}$ & Arrivals \\
\hline $\mathbf{2 0 1 5}$ & 61.797 & 768.887 & 830.684 & 475 \\
\hline $\mathbf{2 0 1 6}$ & 68.169 & 763.561 & 831.730 & 639 \\
\hline $\mathbf{2 0 1 7}$ & 68.105 & 680.813 & 748.918 & 539 \\
\hline $\mathbf{2 0 1 8}$ & 63.138 & 669.293 & 732.431 & 438 \\
\hline $\mathbf{2 0 1 9}$ & 73.110 & 731.771 & 804.881 & 622 \\
\hline
\end{tabular}

Dubrovnik still remains the main port of the Adriatic region in terms of passenger transit. Although in 2017, there was a decrease of $10.8 \%$ in the number of transit passengers in comparison with 2016, and a decrease of $1.7 \%$ in comparison with two previous years. In 2019, there was an increase of $9.89 \%$ in the total number of passengers compared to 2018.

For several years, the Port of Dubrovnik Authority has been trying to limit the number of passengers from cruise ships in accordance with the provisions of the study "Sustainable Development of Cruising Tourism in Croatia" by the Institute for Tourism. A number of measures have been introduced which, in view of the high demand for Dubrovnik as one of the most attractive destinations in the Mediterranean, limit the number of visitors from cruise ships to 8,000 per day. It should be noted that the Port of Dubrovnik only for the 2019 season refused about forty inquiries of large - mega ships, due to the desire to limit the number of passengers from ships on cruises ${ }^{6}$.

\section{The port of Šibenik}

The port of Šibenik is one of the oldest ports on the Croatian side of the Adriatic. It is located 500 meters from the city centre. The Port of Šibenik can accommodate two cruise ships at the same time, one $260 \mathrm{~m}$ and one $200 \mathrm{~m}$ ships, and it can also accommodate cruise ships at anchorage. The intention is to modernize the passenger terminal in the port of Šibenik. The proposed project has an estimated value of around $€ 1.8$ million $^{7}$, which should be financed through a loan from the European Bank for Reconstruction and Development. 
Table 6. Total number of passenger and cruise ship movement in the port of Šibenik in the period from 2015 to 2019

\begin{tabular}{|c|c|c|c|c|}
\hline Year & $\begin{array}{c}\text { Number of passengers } \\
\text { (embarked/ } \\
\text { disembarked) }\end{array}$ & $\begin{array}{c}\text { Number of } \\
\text { passengers } \\
\text { in transit }\end{array}$ & $\begin{array}{c}\text { Total number of } \\
\text { passengers (boarded / } \\
\text { disembarked+transit) }\end{array}$ & Arrivals \\
\hline $\mathbf{2 0 1 5}$ & 0 & 17.562 & 17.562 & 83 \\
\hline $\mathbf{2 0 1 6}$ & 0 & 12.276 & 12.276 & 106 \\
\hline $\mathbf{2 0 1 7}$ & 0 & 27.718 & 27.718 & 109 \\
\hline $\mathbf{2 0 1 8}$ & 0 & 35.729 & 35.729 & 109 \\
\hline $\mathbf{2 0 1 9}$ & 0 & 19.134 & 19.134 & 103 \\
\hline
\end{tabular}

From 2015 to 2018, the port of Šibenik recorded an increase in the total number of passengers by $28.9 \%$ compared to 2017 . According to Table 6 , the number of passengers increased by $103 \%$ compared to 2015 . In 2019 , the number of passengers decreased by $46.44 \%$ compared to 2018 .

Statistical analysis of cruise traffic of the leading ports of the Republic of Croatia in relation to the leading port of the Mediterranean - Barcelona

In the last two decades, the interest in cruises has been growing, which is supported by the fact that in the same time period, the number of cruise passengers in the world has been growing at the rate of about 8 to $9 \%$ per year (Sciozzi et al. 2015). Cruising tourism in the Republic of Croatia is an important segment of tourism that can contribute to economic and social

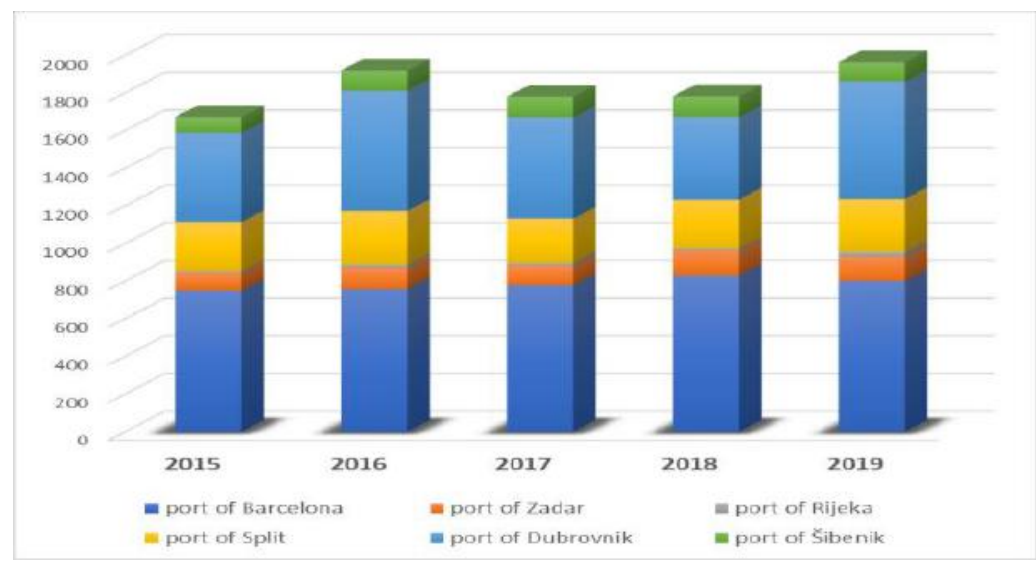

Figure 1. Number of arrivals in the ports of the Republic of Croatia and in the port of Barcelona 
development. Since, in addition to touring various destinations and cultures, it also includes time spent on board, the interest of passengers for this type of travel is extremely high. According to cruise demand trends, cruise tourism has been steadily improving, introducing new routes, destinations, and more equipped cruise ships. Geographical position, weather conditions, natural beauty and historical and cultural attractions play an important role in the choice of destination.

Figure 1 shows the number of arrivals in the ports of the Republic of Croatia in relation to the port of Barcelona. In 2019, the port of Barcelona, as the leading port of the Mediterranean has 800 arrivals. The port of Dubrovnik has 622 arrivals, which is approximately $22 \%$ less than the port of Barcelona. The Port of Split has 282 arrivals, the Port of Zadar 131 arrivals, the Port of Śibenik 103 arrivals, and the Port of Rijeka has the lowest of 24 arrivals.

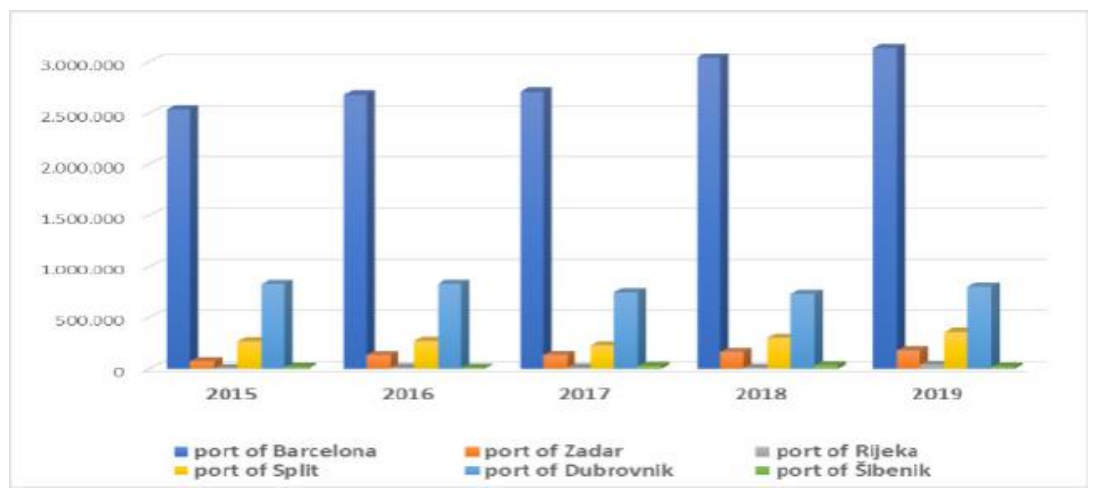

Figure 2. Total number of passengers in the port of Barcelona compared to other ports in the Republic of Croatia

Analysing the total number of embarked, disembarked passengers and passengers in transit (Figure 2), it can be concluded that the port of Barcelona, as the leading port in the Mediterranean, has a 23.53 percent increase in the total number of passengers in 2019 compared to 2015. The largest rapid growth of the total number of passengers in the Republic of Croatia is in the port of Rijeka, 352.95\%, and the port of Zadar $145.16 \%$. The port of Šibenik has an increase of $8.95 \%$, the port of Split $32.61 \%$. Figure 2 shows that the port of Dubrovnik has a decrease in the number of passengers by $3.11 \%$.

\section{Quantification of cruise port model variables}

In order to quantify the selected variables of the information model of cruise ports in the Republic of Croatia, it was necessary to determine the values of variables 
for 2015 and 2019. The value of variables was determined using the statistical report - The Association of Mediterranean Cruise Ports. MedCruise's mission is to promote cruise industry in the Mediterranean, Black Sea, Adriatic Sea, Red Sea and the Atlantic. All the listed ports in this paper are members of MedCruise and their membership today expands to 21 countries and 3 different continents representing more than 130 ports and 30 companies and associations related to cruising.

The quantification of the model variables was performed on an index scale from zero to 100. It was assumed that the value of the variables was zero in underdeveloped countries, and that 100 was the value of the variable of the busiest cruise port in the Mediterranean, Barcelona. Below is the quantification of the variables of the information model of the cruise ports in the Republic of Croatia, based on the resulting mental-verbal considerations in the previous paragraphs of this paper.

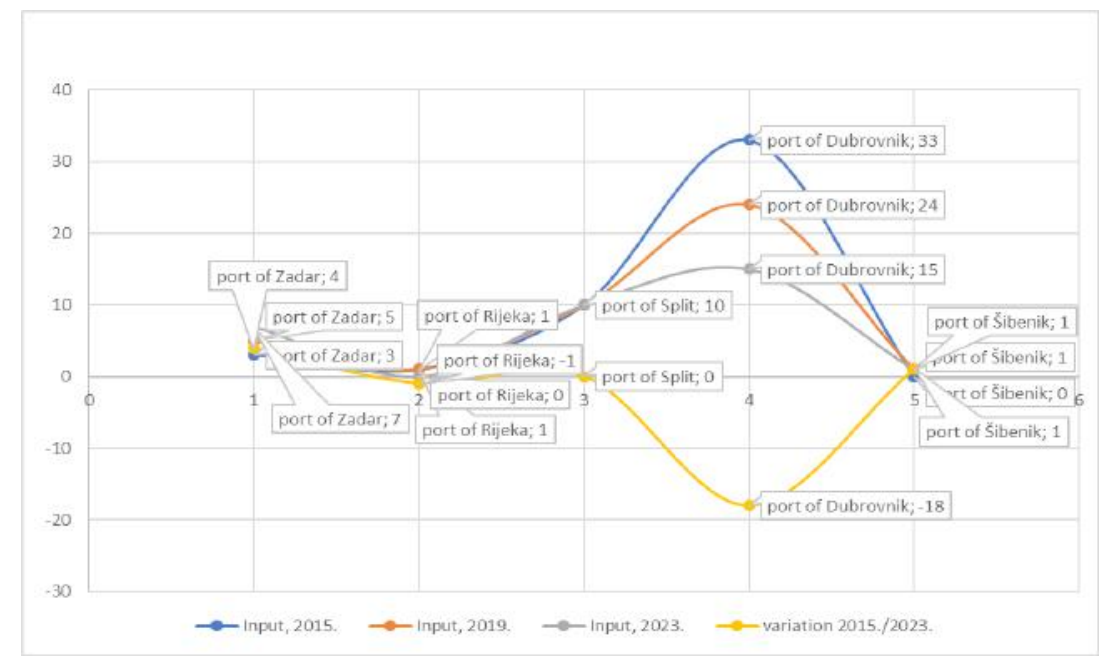

Figure 3. Quantification of variables of cruise port information model in the Republic of Croatia

The quantification of the variables of the information model shows that in 2023 the Port of Dubrovnik variable will have the highest value, even though the number of passengers from cruises in the mentioned port is in a significant decline compared to previous periods.

Also at the same time, the quantification of variables resulted in the lowest value of the variables of the port of Rijeka.

The largest increase from 2015 to 2023 has the Zadar port variable. The main reason is the opening of a new passenger terminal, previously mentioned in the paper, and this is what other Croatian cruise ports lack. 


\section{Conclusions}

Cruising has been growing everywhere in the world, especially in the Mediterranean in the course of the last 10 years by more than $40 \%$, which certainly has an impact on the ports in the Republic of Croatia. This paper analyzes the data for the five largest Croatian cruise ports in Croatia for the period from 2015 to 2019: Dubrovnik, Split, Zadar, Rijeka and Šibenik.

For the first time, the quantified values of variables were obtained. The port of Zadar showed the highest positive value of the quantification of the variables of cruise port in the Republic of Croatia, i.e. 4, while the port of Dubrovnik showed the lowest value, i.e. -18 . It can be concluded that by 2023, Dubrovnik will record an additional decrease in quantified value. At the same time, the quantified value for the port of Zadar is expected to increase.

The port of Barcelona was taken as a reference point for the analysis of cruise ports in the Republic of Croatia, as it is a prominent and favourite destination of all ships cruising the Mediterranean. Annually, more than 2.4 million passengers visit the port of Barcelona. It is often a benchmark for other Mediterranean ports due to its port capacity and infrastructure, and strong connections with other forms of transport. The goal of the research was achieved through the quantification of variables, derived from the mental verbal knowledge, as follows:

the port of Dubrovnik -33 (2015.), 24 (2019), 15 (2023), -18 (2015/2023); the port of Split -10 (2015.), 10 (2019), 10 (2023), 0 (2015/2023); the port of Zadar -3 (2015.), 5 (2019), 7 (2023), 4 (2015/2023); the port of Rijeka -1 (2015.), 11 (2019), 0 (2023), 0 (2015/2023); the port of Šibenik -0 (2015.), 1 (2019), 1 (2023), $1(2015 / 2023)$.

This quantification of variables will be the basis for the calculation of direct growth rates of the model of the most important cruise ports in the Republic of Croatia for 2015, 2019 and 2023 in the further research.

\section{NOTES}

1. The Association of Mediterranean Cruise Ports. Available from: https://www. medcruise.com/

2. https://www.cruiseindustrynews.com/cruise-news/21060-barcelona-3-2million-cruise-guests-in-2019.html (assessed 19.03.2021.)

3. Državni zavod za statistiku; Kružna putovanja stranih brodova u Republici Hrvatskoj u razdoblju od siječnja do studenoga (2019). Available from: https://www.dzs.hr/Hrv_Eng/publication/2019/04-03-05_01_2019.htm (assessed 18.03.2020.)

4. Lučka uprava Zadar. Available from: https://www.luka-zadar.hr/.

5. Lučka uprava Split. Available from: https://portsplit.hr/cruising/. 
6. Lučka uprava Dubrovnik. Available from: https://www.portdubrovnik.hr/kruznaputovanja)

7 Lučka uprava Šibenik. Available from: http://www.portauthority-sibenik.hr.

8. https://hrturizam.hr/ (assessed 25.02.2021.)

9. Port of Barcelona. Available from: http://www.portdebarcelona.cat.

10. Strategija razvoja turizma RH do 2020. Available from: https://mint.gov.hr

11. Studija održivog razvoja kruzing turizma u Hrvatskoj. Zagreb, 2007: Institut za turizam.

\section{REFERENCES}

Peručić, D., 2013. Cruising turizam, razvoj, strategije i ključni nositelji, 64. Dubrovnik.

Šamanović, J., 2002. Nautički turizam i management marina. Split.

Sciozzi, Donald, et al., 2015. Structural analysis of cruise passenger traffic in the world and in the Republic of Croatia. Pomorstvo. 29(1), 8-15.

ORCID iD: 0000-0001-6165-9130

Faculty of Maritime Studies

University of Split Split, Croatia E-mail: mracic@pfst.hr

\section{Katarina Balić}

University of Split Split, Croatia E-mail: katarina.balic@unist.hr

$\triangle$ Mira Pavlinovic Web of Science Researcher ID: AAG-6044-2019

Faculty of Maritime Studies

University of Split Split, Croatia

E-mail: mpavlinovic@pfst.hr

$\triangle$ Antonija Mišura https://orcid.org/0000-0003-3641-0936

Faculty of Maritime Studies

University of Split Split, Croatia

E-mail: amisura@pfst.hr 